\title{
Kesiapan Industri TV Lokal di Jawa Tengah Menuju Migrasi Penyiaran dari Analog ke Digital
}

\author{
Mubarok $^{1}$, Made Dwi Adnjani² \\ 1,2 Fakultas Bahasa dan Ilmu Komunikasi, Universitas Islam Sultan Agung, Semarang, \\ Indonesia
}

\begin{abstract}
ABSTRAK
Proses migrasi penyiaran televisi analog ke digital di Indonesia menyisakan beragam persoalan yang harus dibenahi. Penelitian ini bertujuan untuk mengetahui tanggapan dan kesiapan TV Lokal di Jawa Tengah memasuki era penyiaran digital. Hal ini penting agar proses migrasi membawa keuntungan dan eksistensi bagi keberadaan TV Lokal di Jawa Tengah. Temuan penelitian menunjukkan tentang kesiapan televisi lokal di Jawa Tengah menyambut era penyiaran digital diuraikan dalam beberapa tema yaitu; 1 . pengetahuan tentang migrasi penyiaran analog ke digital, 2 . kesiapan teknologi, kesiapan sumber daya manusia, dan kesiapan konten siaran, 3. Pengembangan Potensi daerah
\end{abstract}

\begin{abstract}
The migration process of analog to digital television broadcasting in Indonesia leaves a variety of issues that must be addressed. This study aims to determine the response and readiness of Local TV in Central Java entering the era of digital broadcasting. This is important so that the migration process brings benefits and existence to the existence of Local TV in Central Java. The research findings show that local television readiness in Central Java welcomes the digital broadcasting era outlined in several themes, namely; 1 . knowledge of analog to digital broadcasting migration, 2. technology readiness, human resource readiness, and broadcast content readiness, 3. Regional potential development
\end{abstract}

KATA KUNCI migrasi; analog; digital; televisi; lokal

KEYWORDS

Migration; analog; television; local

\section{PENDAHULUAN}

Proses migrasi penyiaran televisi dari analog ke digital di Indonesia masih menyisakan beragam persoalan yang harus dibenahi. Beberapa pihak yang berkepentingan dengan proses migrasi tersebut berharap agar UU Penyiaran yang baru bisa segera disahkan sehingga proses migrasi bisa segera dituntaskan. Kepastian hukum menjadi penting sebagai pijakan pengembangan penyiaran digital di Indonesia.

Revisi UU Penyiaran sampai saat ini masih dalam pembahasan sehingga proses migrasi penyiaran analog ke digital di Indonesia belum bisa diselesaikan. Beberapa pembahasan penting yang masih diperdebatkan diantaranya adalah single mux dan multi mux. Dewan Perwakilan Rakyat menyatakan bahwa konsep single mux dikhawatirkan memunculkan 
monopoli siaran baru sehingga perlu diperbaiki. Jalan tengah yang diajukan adalah menggunakan konsep hybrid multiplex. Konsep ini menggabungkan kelebihan yang ada pada single mux dan multi mux.

Proses migrasi tersebut melibatkan berbagai pihak yang semestinya didengarkan pendapatnya sehingga proses migrasi membawa kebaikan bagi semua pihak. Kalangan industri penyiaran menganggap bahwa masyarakat akan dirugikan jika mereka harus membeli televisi baru untuk bisa menerima layanan siaran digital. Televisi yang dimiliki masyarakat pada umumnya belum siap untuk menerima siaran digital sehingga mereka harus membeli tv baru. Kondisi ini dianggap akan merugikan masyarakat. Hal-hal tersebut perlu disosialisasikan dengan benar sehingga masyarakat tidak merasa menjadi pihak yang dirugikan.

Pemerintah melalui Kementrian Komunikasi dan Informatika telah meluncurkan program migrasi dari teknologi analog ke teknologi digital pada penyiaran televisi sejak tahun 2008. Program migrasi penyiaran tersebut dilakukan untuk memenuhi ketentuan internasional tentang siaran televisi digital. International Telecommunication Union (ITU) atau otoritas telekomunikasi internasional memberi batas akhir kepada seluruh negara anggotanya untuk melakukan migrasi penyiaran paling lambat, 17 Juni 2015. Sebagai anggota dari International Telecommunication Union (ITU) maka Indonesia juga mulai melakukan migrasi analog ke digital secara bertahap dan ditargetkan pada tahun 2018 seluruh wilayah Indonesia sudah menggunakan teknologi digital broadcasting ini.

Menurut Buku Putih Komunikasi dan Informatika Indonesia tahun 2012 roadmap Televisi Digital di Indonesia dibagi menjadi 3 tahapan yaitu (Idris et al., 2012) dalam (Azmi, 2013): (a). Tahap I - Persiapan (2009-2013). Tahapan ini merupakan permulaan yaitu transisi penyiaran televisi analog ke televisi digital yang ditandai dengan tiga kegiatan utama yaitu uji coba lapangan (2009), mengeluarkan perizinan baru untuk TV digital (2010) dan moratorium izin baru TV analog (2009-2010). Tahap ini juga merupakan awal periode simulcast yang direncanakan tahun 2010-2017. (b). Tahap II Simulcast 2014-2017, yaitu periode dimana perizinan siaran analog dan digital berjalan bersama-sama. Hal ini ditandai dengan penghentian (cut off) operasional TV analog di kota-kota besar (Daerah Ekonomi Maju /DEM), percepatan izin baru TV digital di Daerah Ekonomi Kurang Maju (DEKM). (c). Tahap III - Analog Switch Off 2018 yaitu penghentian TV Analog secara total di seluruh Indonesia

Salah satu pihak yang berkepentingan dalam proses migrasi adalah TV Lokal. Berdasarkan data dari Asosiasi Televisi Lokal Indonesia (ATVLI) di Jawa Tengah terdapat 26 TV lokal yang tersebar di berbagai kota. Data ini sangat mungkin bertambah seiring pertumbuhan penyiaran lokal di berbagai daerah. 
Berikut nama stasiun televisi lokal di Jawa Tengah:

Tabel 1. Televisi Lokal di Jawa Tengah

\begin{tabular}{|c|c|c|}
\hline Nomor & Stasiun TV & Kota \\
\hline 1 & $\begin{array}{l}\text { Semarang TV - } 53 \text { UHF } \\
\text { Pro TV - } 45 \text { UHF - SINDOtv - Semarang3. TV } \\
\text { Borobudur - } 47 \text { UHF - Kompas TV - Semarang4. } \\
\text { TVKU - } 49 \text { UHF - City TV Network - Semarang }\end{array}$ & Semarang \\
\hline 2 & \begin{tabular}{|lcccc} 
Grabag & TV, & 5 & VHF & Grabag \\
MGTV - & 54 UHF - SINDOtv - & &
\end{tabular} & Magelang \\
\hline 3 & BMS TV - 49 UHF - SINDOtv & Purwokerto \\
\hline 4 & Televis Tegal (TVT) - - - & Tegal \\
\hline 5 & 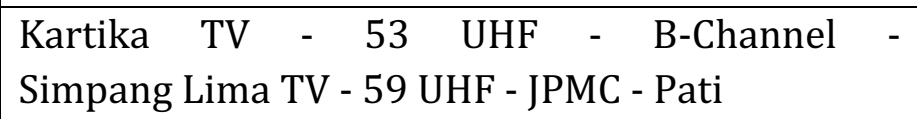 & Pati \\
\hline 6 & Ratih TV - 47 UHF - - & Kebumen \\
\hline 7 & Batik TV - 57 UHF - - & Pekalongan \\
\hline 8 & $\begin{array}{l}\text { TATV Solo - } 50 \text { UHF - - } \\
\text { JK Lentera TV - } 21 \text { UHF - }- \text { Salatiga } \\
\text { Salatìga TV - } 58 \text { UHF - - Salatiga } \\
\text { Satya Wacana TV - } 60 \text { UHF - - Salatiga }\end{array}$ & Solo dan Salatiga \\
\hline 9 & $\begin{array}{l}\text { 3TV - - - Jepara } \\
\text { JSTV - - - Jepara }\end{array}$ & Jepara \\
\hline 10 & Temanggung Tv & Temanggung \\
\hline
\end{tabular}

Penelitian tentang digitalisasi penyiaran telah dilakukan oleh beberapa peneliti dengan beragam sudut pandang, beberapa di antaranya membahas tentang televisi lokal. Peluang dan tantangan dari digitalisasi penyiaran telah diteliti oleh Awaludin (2014), Rizki Hidayat (2015), Amri (2018) dengan rekomendasi bahwa digitalisasi penyiaran tidak bisa hanya dilihat sebagai perpindahan teknologi saja, pemerintah dan masyarakat belum siap, kurangnya sosialisasi dan masih munculnya gangguan siaran. Ashrianto, Panji D (2015) menulis tentang pentingnya melihat kesiapan dari lembaga penyiaran, kemampuan lembaga penyiaran lokal yang sangat terbatas seharusnya menjadi perhatian pemerintah dan tidak hanya berpihak pada yang bermodal besar. Prabowo, A (2015) mengkaji bahwa digitalisasi penyiaran adalah pemberangusan pada televisi lokal dan televisi komunitas, sementara Afifi, S (2012), Budiman, A (2015) mengkaji tentang model pengelolaan digitalisasi penyiaran di Indonesia, sementara Daulat, A (2018) menyatakan bahwa Indonesia menghadapi tantangan regulasi UU Penyiaran dalam mengatur tentang digitalisasi. 
Masduki (2007:106-108) menyatakan bahwa keterbatasan frekuensi, merupakan salah satu hal yang mengindikasikan urgensi pengaturan penyiaran. Tanpa regulasi, maka interferensi signal niscaya terjadi. Ketika itu terjadi, maka aspek dasar komunikasi tidak tercapai. Sebagai ilustrasi sederhana dapat digambarkan bahwa jika pada saat yang bersamaan terdapat dua orang atau lebih berbicara, maka proses komunikasi pasti mengalami kegagalan. Regulasi akan menentukan siapa yang berhak "menyiarkan" dan siapa yang tidak. Dalam konteks demikian regulasi berperan sebagai mekanisme kontrol.

Secara spesifik Mike Feintuck (1999;43-45) mengemukakan bahwa justifikasi penyusunan regulasi penyiaran karena dua hal, yaitu : (1) Komunikasi yang efektif. Selain berhubungan dengan keterbatasan frekuensi, komunikasi efektif juga berkaitan dengan demokratisasi komunikasi yang meliputi jaminan negara untuk memungkinkan terjadinya keberagaman komunikasi. Tanpa regulasi yang menjamin keberagaman penyiaran, kondisi yang berkembang akan cenderung monopolistik. Kondisi yang monopolistik merupakan jembatan emas menuju monopoli informasi, yang berujung pada monopoli kebenaran. Feintuck secara lugas menunjuk kondisi yang demikian sebagai "komunikasi yang tidak efektif"; (2). Diversitas Politis dan Kultural. Diversitas berhubungan dengan dua aspek, yaitu politis dan kultural. Secara politis, diversitas bertalian erat dengan nilai demokrasi yang menghendaki terjadinya aliran ide secara bebas melalui suatu instrumen yang memungkinkan semua orang dapat mengaksesnya secara merata. Jika satu dua orang atau kelompok mendominasi kepemilikan, dan menggunakan posisi tersebut untuk mengontrol isi tampilan media maka ketika itulah terjadi reduksi keberagaman sudut pandang (heterodox view).

Definisi televisi swasta lokal sendiri tidak beda jauh dengan televisi komersial nasional. Dalam UU Nomor 32 tahun 2002 tentang Penyiaran disebutkan, definisi televisi komersial adalah Lembaga penyiaran yang bersifat komersial berbentuk badan hukum Indonesia yang bidang usahanya hanya menyelenggarakan jasa penyiaran televisi. Perbedaan dengan televisi nasional terletak pada daya pancarannya. Dari sisi latar belakang legitimasi politis atas lembaga penyiaran swasta lokal sendiri juga berawal dari pertimbangan yang bersifat ekonomis yaitu, untuk mengeliminir monopoli kepemilikan. Beragam persoalan membelit perkembangan TV Lokal mulai dari aspek permodalan, konten dan survailence bisnis (Harianto, 2012). Banyak yang harus gulung tikar karena persoalan tersebut. Untuk membuat konten yang bagus membutuhkan biaya tinggi. Hasil penelitian (Prabowo, 2012) mempertanyakan nasib TV Lokal di era migrasi penyiaran. Harga sewa mux yang mahal membuat televisi lokal sulit untuk menjangkaunya.

Persoalan yang membelit penyiaran lokal ketika memasuki penyiaran digital adalah biaya sewa mux yang mahal, tantangan produksi konten, persiangan dengan televisi nasional, kepercayaan pengiklan yang masih rendah. Berdasar pada uraian tersebut maka Penelitian ini bertujuan untuk mengetahui tanggapan dan kesiapan TV Lokal di Jawa Tengah memasuki era penyiaran digital. Hal ini penting agar proses migrasi membawa keuntungan dan eksistensi bagi keberadaan TV Lokal di Jawa Tengah. 
Migrasi penyiaran analog ke digital dilandasi oleh beberapa keuntungan yang akan diperoleh baik oleh pemerintah, industri penyiaran maupun masyarakat sebagai konsumen. Digitalisasi terhadap penyiaran Televisi (TV) dilakukan agar dapat meningkatkan efisiensi penggunaan spektrum frekuensi, efisiensi infrastruktur industri penyiaran, dan membuka peluang usaha baru bagi industri konten. Dari sisi kualitas siaran, pemancar TV Digital juga memiliki kualitas gambar dan warna yang jauh lebih bagus daripada televisi analog. Selain itu, televisi digital dapat dioperasikan dengan daya yang rendah (less power), dibandingkan dengan televisi analog. Ketahanan sinyal digital terhadap gangguan suara (noise) lebih baik dan lebih mudah untuk diperbaiki dengan kode koreksi error (error correction code). Pada penyiaran dengan teknologi analog, pembawa satu frekuensi (one-frequency carrier) hanya dapat membawa satu program siaran. Sementara dengan teknologi digital one-frequency-carrier dapat membawa beberapa program siaran pada waktu yang bersamaan melalui pembagian kanal. Tujuan dari program ini adalah untuk meningkatkan efisiensi spektrum frekuensi, efisiensi infrastruktur industri penyiaran, mempertahanan diversity of ownership, menumbuhkan industri konten (diversity of contents), memperoleh digital dividend yang dapat digunakan untuk broadband kebencanaan (Public Protection and Disaster Relief), pendidikan dan lainnya. Penyiaran digital juga menghemat biaya listrik sebesar 94\%, biaya modal (Capital Expenditure) sebesar 79\% dan biaya operasional (Operational Expenditure) sebesar 57\% dibandingkan dengan tetap menggunakan pemancar TV Analog. Penyiaran digital juga meningkatkan kualitas penerimaan siaran TV lebih baik dari penyiaran analog (Cahyarini, 2017).

Pemerintah selalu mengemukakan bahwa perpindahan teknologi ini adalah sesuatu yang harus dilakukan karena dunia juga sudah melakukan perpindahan teknologi ini. Seluruh negara di benua Eropa, Amerika dan Australia telah menyelesaikan proses migrasi. Kondisi global menunjukkan bahwa 85 persen wilayah dunia sudah mulai mengimplementasikan televisi digital. Jepang melakukan analog switch off pada Juli 2011, Korea Desember 2012, China tahun 2012, UK Oktober 2012. Di sebagian besar negara Asia juga hampir selesai, kecuali negara di Asia Barat. Di Asean, Indonesia termasuk negara yang tertinggal dalam peralihan teknologi penyiaran digital. (http://www.tvdigital. kominfo.go.id). Di samping itu pemerintah juga selalu mewacanakan tentang manfaat yang akan diperoleh dengan adanya perpindahan teknologi dari analog ke digital. Berbagai kelebihan ditawarkan oleh teknologi ini, mulai dari suara yang jernih, gambar yang bening, sampai pada tersedianya banyak kanal untuk menyalurkan siaran televisi. Namun demikian, sejumlah problem pun muncul. Mulai dari yang sederhana berupa pengaturan kanal yang jumlahnya jauh lebih besar, sampai yang paling rumit yakni mengatur penyedia jaringan (network provider) dan penyedia konten siaran (content provider) yang akan turut bermain meramaikan dunia penyiaran tanah air. Tidak kalah pelik, adalah memikirkan bagaimana nasib para penyelenggara siaran televisi komunitas dan televisi lokal yang akan memiliki beban yang berat ketika ikut bermigrasi ke TV digital. Padahal kehadiran televisi komunitas dipandang penting untuk 
menjamin demokratisasi penyiaran, khususnya dari sisi keberagaman isi (diversity of content). (Bharata, 2012)

Berbagai problematika dari proses migrasi penyiaran analog ke digital di Indonesia inilah yang menyebabkan migrasi penyiaran di Indonesia belum bisa terwujud. Hambatan penerapan digitalisasi penyiaran TV menurut Kementerian Komunikasi dan Informatika diantaranya (Cahyarini, 2017): (1) Implementasi digitalisasi sistem penyiaran harus didasari regulasi yang kuat di level undang-undang sedangkan Indonesia belum memilikinya. (2) Implementasi migrasi siaran TV Analog ke Digital (digitalisasi) memerlukan biaya tinggi bagi lembaga penyiaran lokal, komunitas, dan juga masyarakat kelas menengah ke bawah, khususnya bagi lembaga penyiaran yang sudah berinvestasi tinggi dalam penyelenggaraan siaran analog. Karena dengan diberlakukannya digitalisasi menyebabkan infrastruktur analog tidak dapat digunakan lagi dan semua materi siaran akan disiarkan oleh Lembaga Penyiaran Penyelenggara Penyiaran Multiplexing (LPPPM), (3) Belum diaturnya pengawasan sistem digital dan sanksi terhadap pelanggaran konten (program siaran).

Perubahan penyiaran dari analog ke digital akan mempengaruhi aspek konten, pola bisnis penyiaran, distribusi konten. Saat ini setidaknya ada tiga bentuk teknologi penyaluran konten siaran televisi sampai kepada penonton. Menurut (Jerome \& Marco, 2014) ketiga bentuk teknologi tersebut adalah terrestrial, kabel dan satelit. Salah satu pihak yang terlibat dalam proses migrasi penyiaran analog ke digital adalah stasiun TV lokal. Menurut (Juditha, 2015) kehadiran televisi lokal merupakan upaya mengakomodasi demokrasi penyiaran, yakni otonomi publik, keberagaman konten dan keberagaman kepemilikan. Salah satu pokok pikiran dari amanah ini terkait konten dengan kearifan lokal yang harus diberi porsi lebih besar. Kenyataannya masalah yang dihadapi televisi lokal saat ini antara lain persaingan antar lembaga penyiaran, sumber daya manusia serta infrastruktur yang kurang memadai menjadikan televisi lokal mengalami banyak hambatan dalam proses produksi konten lokal.

Hasil penelitian (Hendrawan, 2013) menyatakan fungsi sosial televisi tidak bisa tercipta dengan sendirinya. Fungsi televisi lokal sebagai medium ranah publik dan identitas budaya tidak dapat dipisahkan dari karakter komersial. Hasil penelitian ini menunjukkan bagaimana kiprah televisi lokal dari aspek komersial di daerah membentuk karakter dan identitasnya dalam dunia penyiaran. Hasil Penelitian dari (Dirgahayu \& Sunarsi, 2017) menunjukkan kontribusi siaran televisi lokal efektif dan efisien untuk berperan sebagai media sosialisasi sesuai dengan fungsi yang dimilikinya. Kehadiran siaran lokal diharapkan juga mampu menjadi jembatan perkembangan daerah karena minimnya kehadiran kearifan lokal dalam penyiaran televisi nasional. Televisi nasional merujuk pada hasil penelitian (Arzak, 2014) seringkali membawa muatan-muatan tertentu yang secara tidak langsung akan menyampaikan pesan sesuai keinginan mereka. Kepentingan politik dan ekonomi yang berdiri di belakangnya akan menentukan arah siaran televisi nasional. Migrasi penyiaran analog ke digital akan merubah berbagai aspek terkait bisnis 
penyiaran. Hal ini berpengaruh pada perubahan karakteristik, identitas dan konten siaran televisi lokal di daerah. Karena itu televisi lokal merupakan salah satu stakeholder yang berkepentingan terhadap proses migrasi penyiaran di Indonesia.

\section{METODOLOGI PENELITIAN}

Penelitian ini menggunakan pendekatan deskriptif kualitatif untuk mengetahui bagaimana kondisi sekarang terkait kesiapan televisi lokal di Jawa Tengah dalam memasuki era penyiaran digital. Data Primer diperoleh melalui pengisian kuesioner dan wawancara dengan narasumber penelitian dari Batik TV Pekalongan, Temanggung TV, Kontributor daerah SCTV, Udinus TV, dan NET JATENG. Data sekunder diperoleh melalui kajian pustaka dan penelaahan dokumen terkait migrasi penyiaran dari analog ke digital yang dipublikasikan oleh Kementrian Komunikasi dan Informatika. Data tersebut diperoleh dari Laporan Kinerja Kementrian Komunikasi dan Informatika 2017. Hasil kuesioner disajikan dalam bentuk tabel dan grafik prosentase jawaban. Data hasil wawancara diuraikan untuk melengkapi hasil kuesioner, menjelaskan maksud dari jawaban responden yang telah dituangkan dalam kuesioner.

\section{HASIL DAN PEMBAHASAN}

Kehadiran penyiaran digital bisa menjadi wadah industri penyiaran lokal yang terus tumbuh. Model penyiaran analog dimana satu kanal frekuensi hanya bisa digunakan untuk satu stasiun televisi tidak bisa menampung pertumbuhan penyiaran lokal tersebut. Pemohon izin LPS (Lembaga Penyiaran Swasta) Lokal terus tumbuh setiap tahunya sehingga dibutuhkan kanal frekuensi yang memadai. Penyiaran digital memungkinkan satu frekuensi digunakan oleh 9 sampai 12 program siaran. Untuk bisa berperan di era penyiaran digital dibutuhkan kesiapan teknologi, sumber daya manusia (SDM), konten siaran dan dukungan keuangan yang selama ini menjadi persoalan rumit bagi industri penyiaran lokal. Temuan penelitian tentang kesiapan televisi lokal di Jawa Tengah menyambut era penyiaran digital diuraikan dalam beberapa tema yaitu; 1 . pengetahuan tentang migrasi penyiaran analog ke digital, 2. kesiapan teknologi, kesiapan sumber daya manusia, dan kesiapan konten siaran, 3. Pengembangan Potensi daerah. Tema-tema ini dirangkum dari jawaban responden penelitian yang dituangkan dalam kuesioner dan hasil wawancara.

\section{Tema 1: Pengetahuan tentang migrasi penyiaran dan keuntungan bagi TV lokal}

Sosialisasi migrasi penyiaran analog ke digital belum dilakukan secara massif. Beberapa kegiatan sosialisasi masih terpusat di kota-kota tertentu dengan skala kecil. Meskipun sosialisasi migrasi analog ke digital belum dilakukan secara massif kalangan pelaku penyiaran di Jawa Tengah telah mengetahui program tersebut. Jumlah responden yang 
tidak mengetahui rencana migrasi penyiaran analog ke digital hanya $9 \%$ artinya sebagian besar sudah mengetahui rencana migrasi tersebut.

\section{Grafik.1 Pengetahuan Rencana Migrasi Penyiaran}

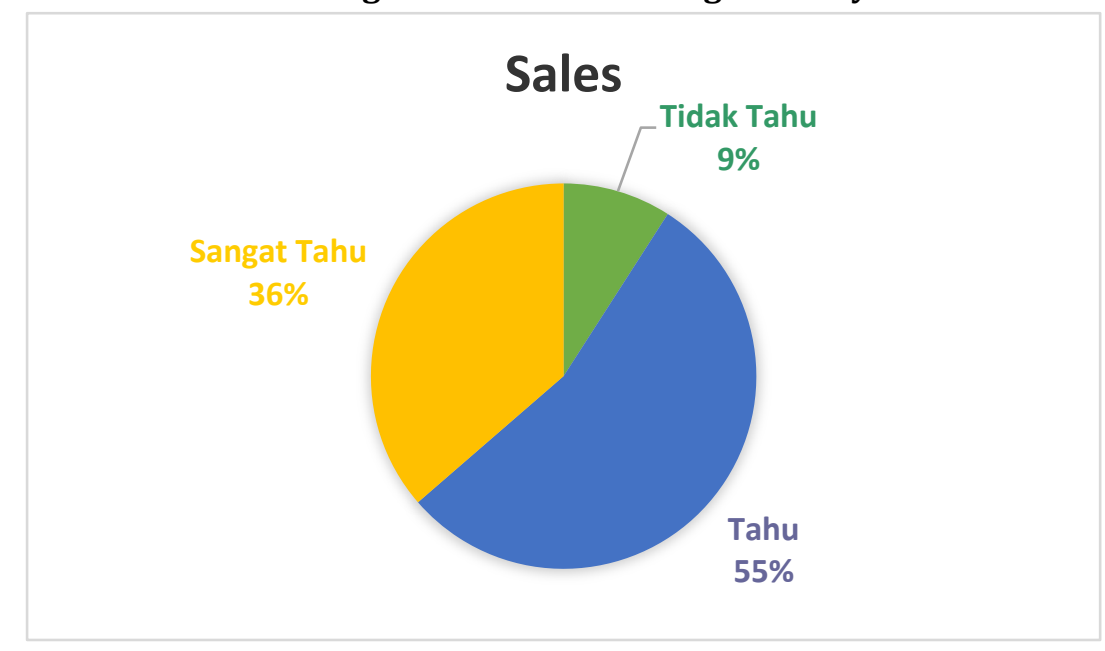

Mereka mengetahui rencana migrasi tersebut melalui seminar maupun informasi yang diperoleh melalui internet. Pengetahuan mereka tentang migrasi penyiaran analog ke digital meliputi keunggulan kualitas gambar dibanding analog, ketersediaan kanal yang lebih banyak dan pemanfaatan penyiaran digital untuk kepentingan multimedia.

Uji coba siaran TV Digital saat ini sudah berlangsung (on air) dan diikuti oleh LPS Penyedia Konten di 12 kota (wilayah layanan), yaitu Jabodetabek, Bandung, Yogyakarta, Medan, Batam, Surabaya, Semarang, Denpasar, Palembang, dan Makassar.

\section{Gambar 1. Peta jangkauan Siaran dan Ujicoba Penyiaran Digital}

$\begin{array}{ll}\begin{array}{l}\text { Peraturan Menteri Komunikasi dan Informatika } \\ \text { Nomor } 5 \text { Tahun } 2016\end{array} & \text { Keputusan Menteri Komunikasi dan } \\ \begin{array}{l}\text { Uji Coba Teknologi Telekomunikasi, Informatika, } \\ \text { Informatika Nomor } 1227 \text { Tahun } 2017\end{array} \\ \begin{array}{l}\text { Uji Coba Siaran Televisi Digital Teresterial } \\ \text { Ian }\end{array}\end{array}$

Uji Coba TV Digital Tahap III (9 Juni 2017 - 9 Juni 2018)

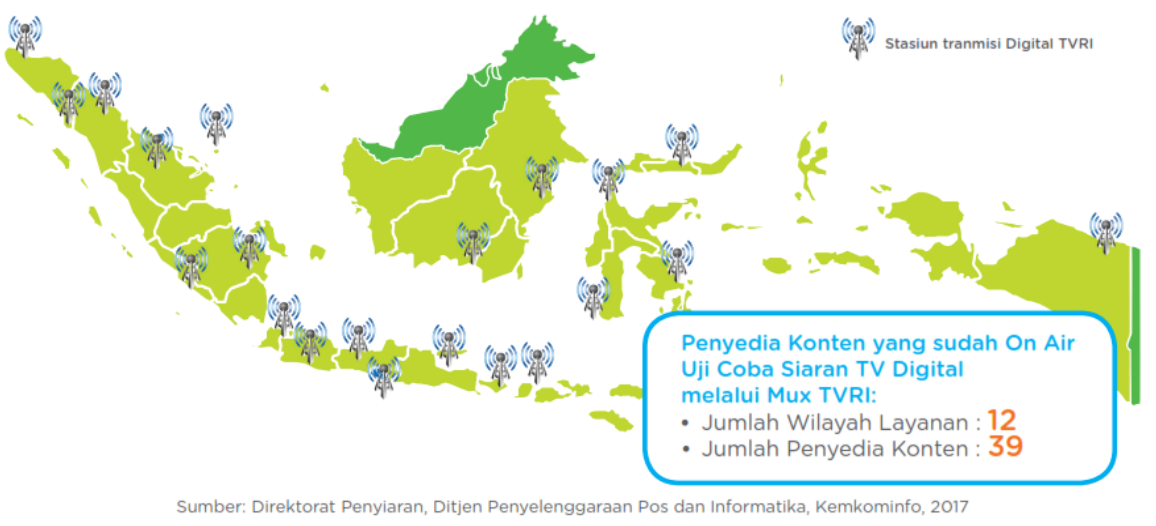

Sumber: Kemkominfo (2017)

Hasil uji coba tersebut menambah keyakinan pengelola televisi lokal akan keunggulan penyiaran digital. Mereka mendukung proses migrasi tersebut. Hal itu nampak pada tabel 
berikut yang menunjukkan $50 \%$ reponden menyatakan cukup mendukung, 40\% mendukung dan 10\% sangat mendukung proses migrasi penyiaran analog ke digital.

Tabel 2. Dukungan TV Lokal Terhadap Proses Migrasi

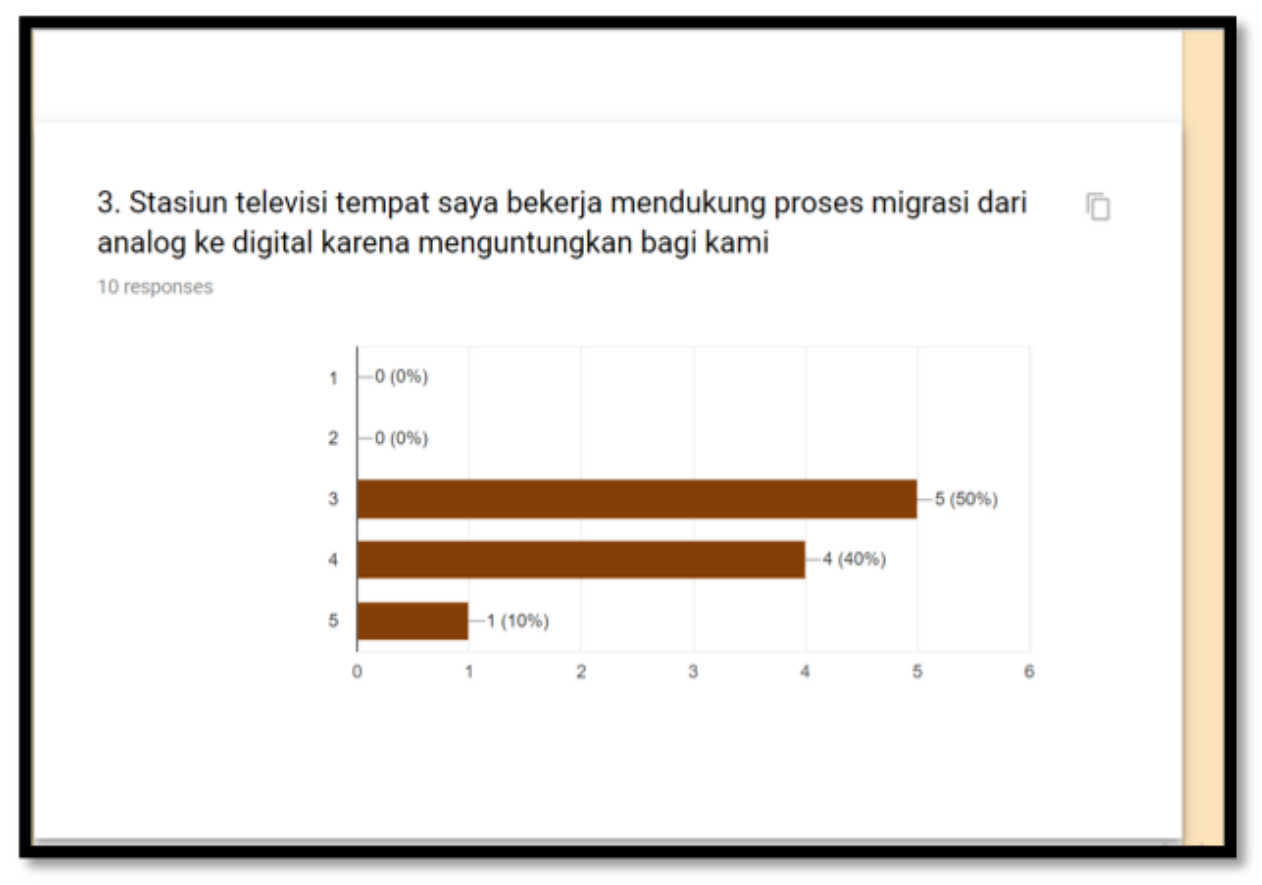

Kalangan pengelola TV lokal di Jawa Tengah mendukung proses migrasi penyiaran analog ke digital karena akan membawa keuntungan bagi mereka. TV lokal bisa berkembang dengan kesempatan yang diberikan karena munculnya banyak kanal yang bisa diisi. Keterbukaan jalan ini dianggap sebagai suatu kesempatan untuk berkembang.

Tabel 3. TV Lokal Bersaing Dengan TV Nasional

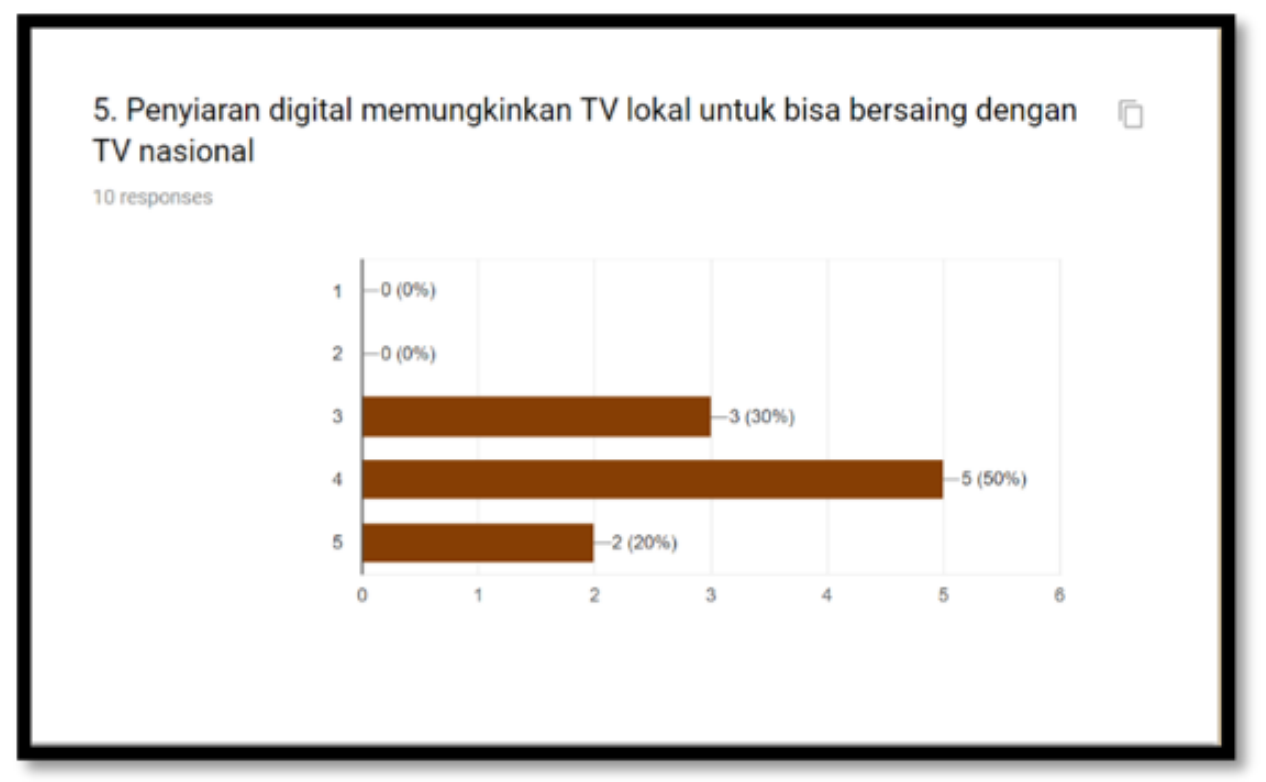


Selama ini TV Lokal kesulitan untuk bersaing dengan siaran TV Nasional. Pelaku industri penyiaran lokal merasa yakin mereka akan mampu bersaing dengan TV Nasional ketika proses migrasi sudah dilakukan. Frekuensi yang bisa digunakan untuk banyak saluran diyakini akan menumbuhkan industri TV Lokal dan juga konten lokal.

\section{Tema 2. Kesiapan teknologi, sumber daya manusia dan konten siaran}

Industri televisi harus siap menghadapi perubahan termasuk migrasi penyiaran analog ke digital. Industri penyiaran di daerah sudah siap menyambut proses migrasi penyiaran. Mereka menyiapkan teknologi dan sumber daya manusia sejak dini sehingga siap menghadapi proses migrasi. Mereka harus tetap memegang visi dan misi yang telah ditetapkan sebagai rujukan pengembangan televisi di daerah.

Tabel 4. Kesiapan Teknologi TV Lokal

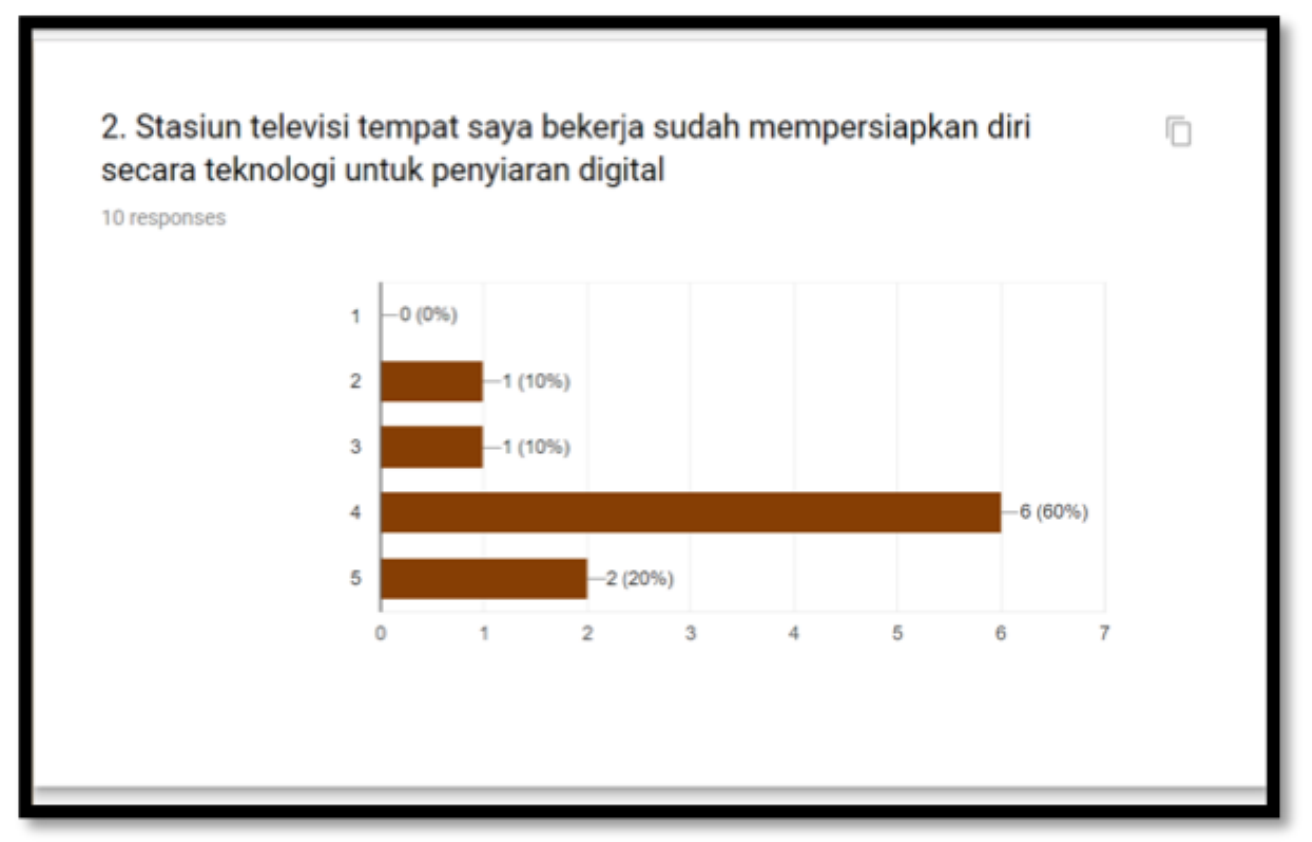

Stasiun TV lokal di Jawa Tengah sudah mempersiapkan teknologi yang dibutuhkan untuk melakukan migrasi siaran dari analog ke digital. Mereka menganggap tinggal menunggu waktu proses migrasi tersebut akan berjalan sehingga mereka sudah mempersiapkan diri sejak dini. Sebanyak 60\% responden menyatakan bahwa stasiun televisi tempat mereka bekerja sudah mempersiapkan teknologi yang memadai untuk menyambut era penyiaran digital. 
Tabel 5. Kesiapan SDM TV Lokal

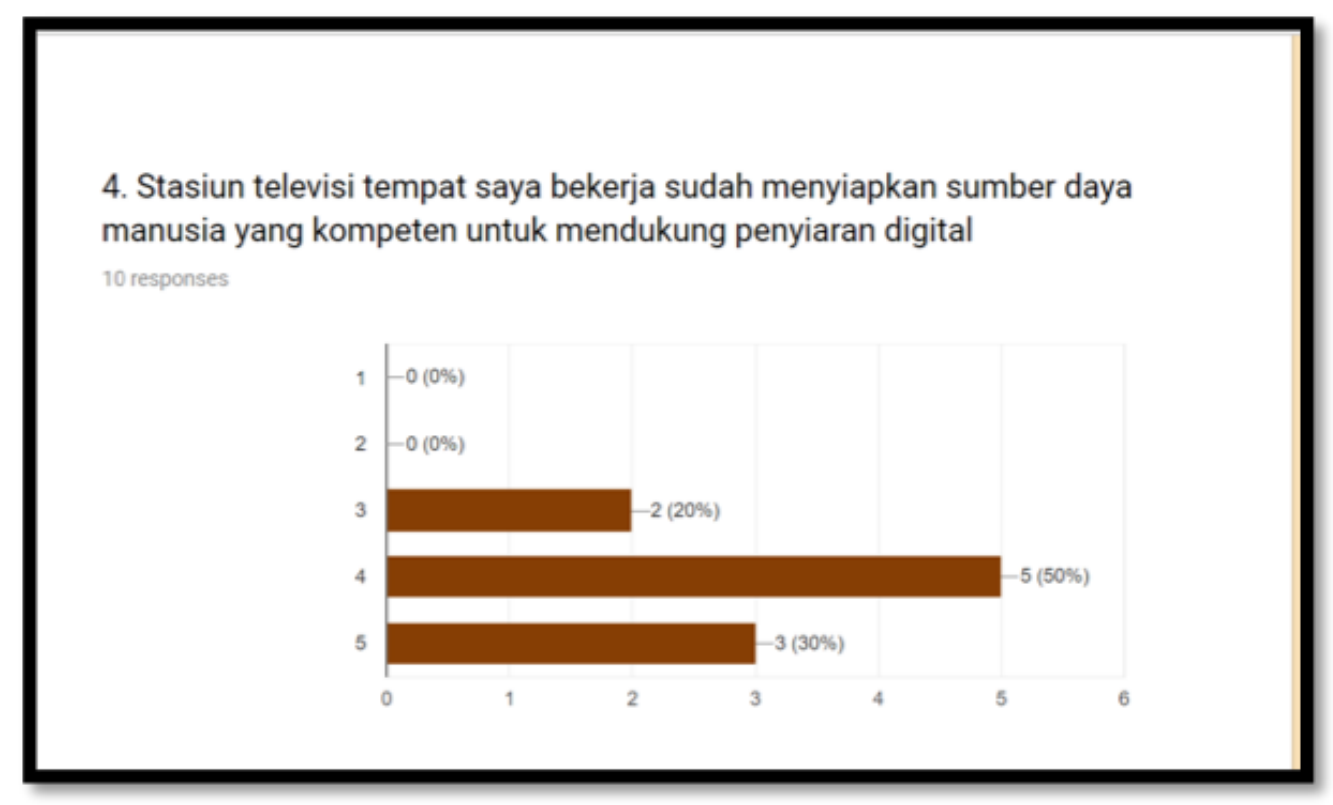

Upaya yang dilakukan oleh pengelola TV Lokal untuk menyambut kehadiran migrasi analog ke digital adalah dengan menyiapkan sumber daya manusia yang kompeten. Kemampuan teknis, kemampuan mengelola siaran dan kemampuan manajerial dikembangkan agar mereka siap menyambut proses migrasi. Pelaku industri penyiaran di daerah merasa telah siap untuk menyambut proses migrasi analog ke digital. Mereka tidak memiliki kendala baik dari sisi teknis maupun SDM. Satu hal yang masih menjadi keraguan adalah proses kejelasan peta jalan migrasi yang belum diumumkan sehingga mereka belum mengetahui secara pasti posisi TV lokal dalam peta jalan migrasi tersebut.

\section{Tema 3. Pengembangan Potensi Daerah}

Proses migrasi penyiaran diaharapkan bisa melahirkan demokratisasi penyiaran dimana akses dan kesempatan terbuka lebar untuk berbagai kalangan. Konglomerasi media dan monopoli bisa ditekan sehingga demokratisasi penyiaran bisa tumbuh. TV Lokal harus bisa menghasilkan konten dengan kearifan lokal yang berbeda sehingga memiliki keunggulan komparatif. Potensi seni, budaya, ekonomi, pariwisata yang ada di daerah bisa dikembangkan sebagai materi siaran. 
Tabel 6. TV Lokal Berkembang di Daerah

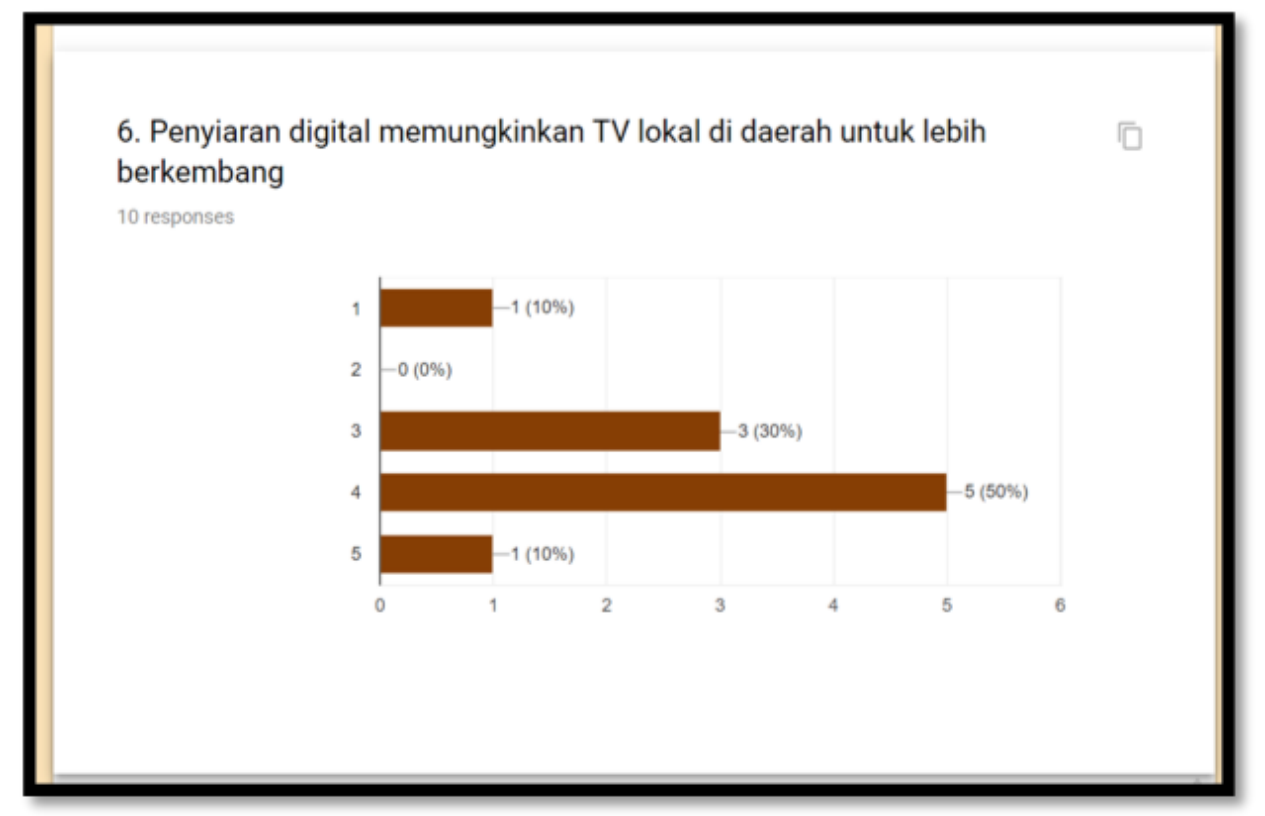

Pengelola TV lokal di daerah selama ini merasa sulit untuk berkembang di daerah. Kualitas gambar, siaran dan program yang kalah dari TV nasional membuat mereka tidak diminati oleh pemirsa di daerah. Proses migrasi dari analog ke digital memungkinkan kualitas siaran lebih baik, kualitas gambar lebih baik sehingga industri TV Lokal bisa berkembang. Selain kualitas siaran pengelola TV lokal juga mengembangkan program acara berdasarkan kebutuhan pemirsa di daerah. TV lokal di daerah menggunakan tahapan pra produksi, produksi dan pasca produksi ketika membuat program acara. Dalam tahapan pra produksi mereka melakukan observasi dan riset untuk mengetahui kebutuhan pemirsa di daerah. Sehingga program acara yang dibuat sesuai dengan kebutuhan pemirsa di daerahnya. Program acara yang dibuat berdasarkan kebutuhan pemirsa di daerahnya membuat acara tersebut mendapatkan respon yang baik dari pemirsanya. Berita lokal dan berbagai kearifan lokal yang ditampilkan menjadikan siaran TV lokal berbeda dengan TV nasional. Aspek keunggulan budaya daerah dan pendidikan lebih kental dalam program acara mereka. Guna bersaing dengan TV Nasional pengelola TV lokal memiliki beberapa program keunggulan yang tidak dimiliki oleh stasiun TV Nasional. Sebagai contoh Batik TV Pekalongan memiliki keunggulan program religi seperti: menapak tanah suci, safari ngaji, rohani islam, iqro dan Islam nafasku. Program unggulan untuk mengembangkan seni budaya diantaranya: Batik TV membuat acara Ranah Budaya untuk mengembangkan potensi seni budaya di Pekalongan seperti batik. Temanggung TV membuat acara Melestarikan Cengklungan. Program siaran pendidikan Batik TV: SMK Bisa, Apa Katanya, Aku dan Hobiku. Potensi wisata di daerah seperti Batik Pekalongan menjadi salah satu program unggulan yang masuk dalam program acara televisi. Potensi wisata alam yang dikaitkan dengan potensi ekonomi didaerah juga bisa menjadi materi siaran TV Lokal. Siaran persatuan dan kesatuan Batik TV contohnya Indonesia Raya. Penyiaran di daerah berfungsi erat untuk merekatkan persatuan dan kesatuan bangsa. Fungsi ini dijalankan oleh industri penyiaran di daerah dengan 
membuat program-program yang mengarahkan masyarakat untuk selalu memelihara persatuan dan kesatuan.

Beragam potensi daerah yang dikembangkan menjadi materi penyiaran direspon dengan baik oleh masyarakat. Hal ini juga menumbuhkan kepercayaan dari produsen di daerah untuk mengiklankan produk mereka di TV Lokal.

Tabel 7. Iklan di TV Lokal

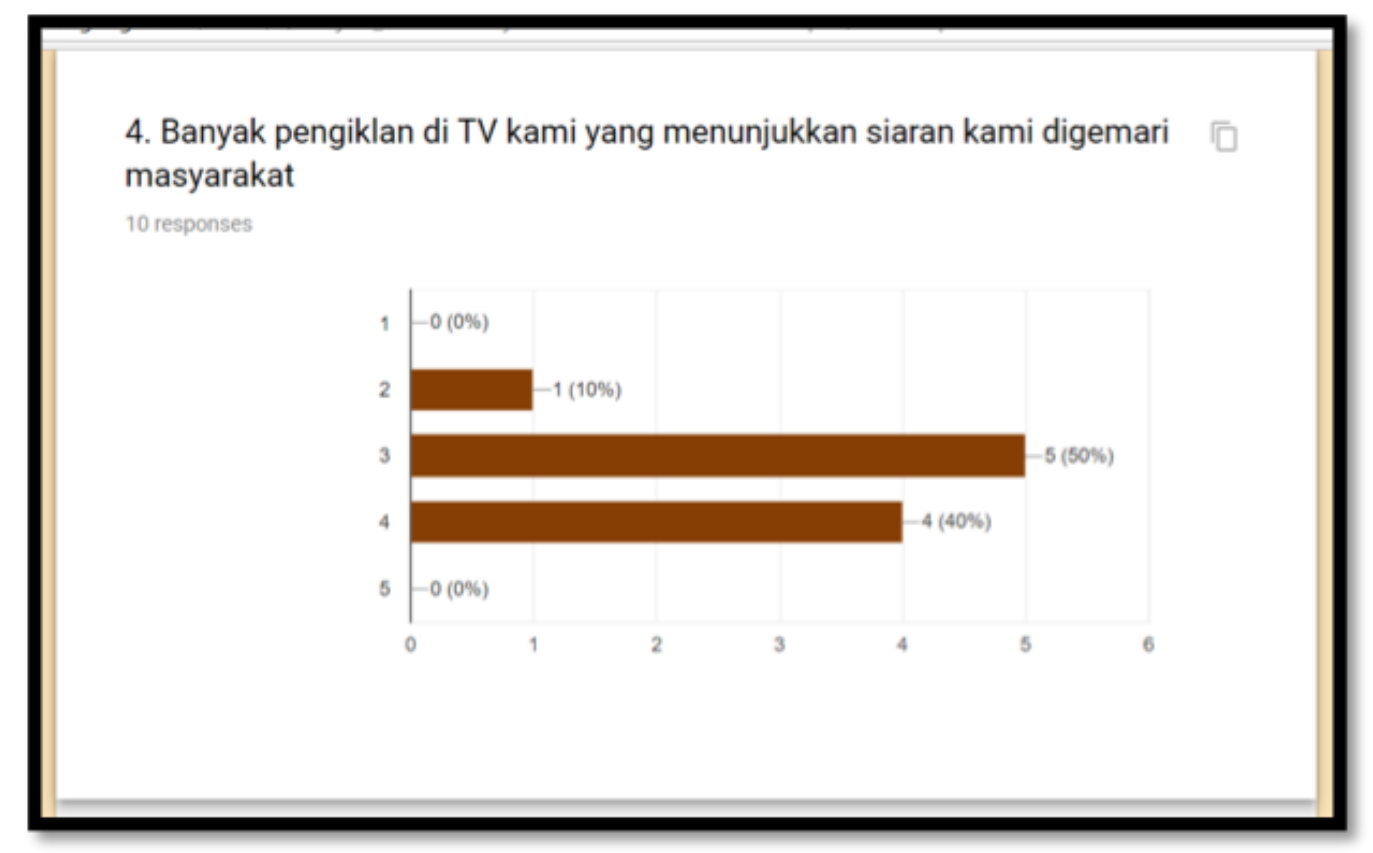

Kualitas siaran yang baik, gambar yang sudah sesuai standar penyiaran menjadikan respon pemirsa terhadap siaran Tv lokal sangat positif. Respon positif masyarakat diikuti dengan pertumbuhan iklan sebagai salah satu sumber pendapatan. Pertumbuhan iklan di daerah menjadikan Tv Lokal mampu hidup dan berkembang. Pertumbuhan iklan yang positif diharapkan mampu menopang keberlangsungan program siaran TV Lokal. Pada industri televisi swasta iklan menjadi nafas kehidupan dan tumpuan keberlangsungan media televisi (Mustika, 2012)

\section{SIMPULAN}

Kalangan pengelola TV lokal di Jawa Tengah mendukung proses migrasi penyiaran analog ke digital karena akan membawa keuntungan bagi mereka. TV lokal bisa berkembang dengan kesempatan yang diberikan karena munculnya banyak kanal yang bisa diisi. Keterbukaan jalan ini dianggap sebagai suatu kesempatan untuk berkembang. Migrasi penyiaran dari analog ke digital lebih dari sekedar pergantian teknologi melainkan diharapkan menumbuhkan demokratisasi di bidang penyiaran. Migrasi penyiaran dari analog ke digital diharapkan bisa mewujudkan demokratisasi di sektor penyiaran. Selama ini ruang media masih dikuasasi oleh sekelompok orang pemodal 
besar sehingga ruang bagi kelompok kecil berkurang. Demokratisasi penyiaran dengan kedaulatan di tangan public diharapkan muncul di era TV digital. Regulasi yang diterpakan terhadap TV Lokal harus dilandasi semangat untuk mendukung mereka tumbuh dan berkembang. Sebagai contoh regulasi yang memudahkan perijinan, memudahkan pengembangan conten siaran, kemudahan perpajakan dan dukungan penggunaan teknologi. Banyak TV lokal yang membutuhkan perhatian pemerintah karena keterbatasan kemampuan sehingga dukungan regulasi sangat dibutuhkan.

Pengelola TV Lokal di Jawa Tengah menyatakan kesiapanya dalam melakukan migrasi penyiaran dari analog ke digital. Mereka telah menyiapkan teknologi pendukung, sumber daya manusia dan juga konten lokal. Keyakinan pengelola TV Lokal di Jawa Tengah muncul karena kanal digital akan membuka ruang bagi mereka untuk tumbuh. Selain itu penyiaran digital juga bagian dari upaya demokratisasi penyiaran sehingga monopoli segelintir pihak dapat diminimalkan. Kehadiran penyiaran digital juga diyakini mampu mengekplorasi potensi daerah melalui penyiaran TV Lokal.

\section{DAFTAR PUSTAKA}

Afidah, A.N., Doom, M., \& Putri, R.N.S. (2017). Laporan Kinerja Kominfo 2017. (Ismail, S. Fridaningrum, \& H. Aryfianto, Ed.). Kementrian Komunikasi dan Informatika. https://web.kominfo.go.id/sites/default/files/FINAL\%20FA\%20LAKIP\%20KOMI NFO\%202017.pdf

Arzak, M. (2014). Ical di Mata Televisi dan Korban Lumpur Lapindo. Jurnal ILMU KOMUNIKASI, 11(1), 67-80. https://doi.org/10.24002/jik.v11i1.385

Azmi, R. (2013). Analisis Model Bisnis Penyelenggaraan Televisi Digital Free-to-Air di Indonesia. Buletin Pos Dan Telekomunikasi, 11(4), 265-280. http://dx.doi.org/10.17933/bpostel.2013.110401

Bharata, B.S. (2012, Maret 27). Lagi, Revisi Undang-Undang Penyiaran. FISIP-Universitas Atma Jaya Yogyakarta. https://fisip.uajy.ac.id/2012/03/29/lagi-revisi-undangundang-penyiaran/

Dirgahayu, D., \& Sunarsi, R. (2017). Kontribusi Media Televisi Lokal dalam Menyosialisasikan Program Revolusi Mental. Jurnal Penelitian Komunikasi, 20(2), 175-188. https://doi.org/10.20422/jpk.v20i2.130

Harianto, R. (2012). Realitas TV Lokal dan Celah Hukum: Studi Kasus Kerjasama Kompas TV dan BCTV Surabaya. Jurnal Komunikasi Islam, 02(01), 84-102. Retrieved from http://jki.uinsby.ac.id/index.php/jki/article/view/38/32

Hendrawan, B. (2013). Televisi Lokal: Antara Kepentingan Korporat. Jurnal Ilmu Komunikasi, II(April), 5-14. https://doi/org/10.7454/jki.v2i1.7825

Jerome, A., \& Marco, O. (2014). The Transition to Digital Television. International Journal of Digital Televison, 1(1), 7-29. https://doi.org/10.1386/jdtv.1.1.7/1 
Juditha, C. (2015). Televisi lokal dan Konten Kearifan Lokal (STUDI KASUS DI SINDO TV KENDARI). Penelitian Komunikasi Dan Pembangunan, 16(1), 49-64. http://dx.doi.org/10.31346/jpikom.v16i1.1337

Mustika, R. (2012). BUDAYA PENYIARAN TELEVISI DI INDONESIA. Masyarakat Telematika Dan Informasi, 3(1), 51-56. Diperoleh dari https://mti.kominfo.go.id/index.php/mti/article/view/35

Prabowo, A. (2012). Era Penyiaran Digital: Pengembangan atau Pemberangusan TV Lokal dan TV Komunitas? Jurnal ASPIKOM, 1(4), 301-314. https://doi.org/10.24329/aspikom.v1i4.27 